\title{
Rekabet mi, İşbirliği mi? Firmaların Büyüme ve Uluslararasılaşma Kararlarında Tedarikçilerinden Beklentilerine İlişkin Nitel Bir Çalışma
}

\section{Prof. Dr. Recai Coșkun ${ }^{1 *}$ Kevser Sancaktutan ${ }^{2}$}

Geliş tarihi: 25.12.2018

Kabul tarihi: 09.01.2019

\section{Atıf bilgisi: \\ Uluslararası Bilimsel Araştırmalar Dergisi (IBAD) \\ Cilt: $4 \quad$ Sayı: 1 \\ Sayfa: 21-33 Yıl: 2019 \\ Dönem: Kış}

This article was checked by Turnitin. Similarity Index 01\%

1'zzmir Bakırçay Üniversitesi, Türkiye, recai.coskun@bakircay.edu.tr ORCID ID 0000-0002-5200-6098

${ }^{2}$ Sakarya Üniversitesi, Türkiye, kevsersancaktutan@gmail.com ORCID ID 0000-0002-5649-1844

* Sorumlu yazar öz

Çalıșma, firmaların büyüme ve uluslararasılaşma kararlarında tedarikçilerden beklentilerini ve firma-tedarikçi ilişkisinde geleneksel/rekabetçi mi yoksa işbirlikçi bir yaklașımın $\mathrm{mı}$ benimsendiğini saptamak amacıyla yürütülmüștür. Nitel araștırma olarak tasarlanan çalışmada belirlenen yedi firma yöneticisiyle mülakat yapılmış ve firmaların tedarikçilerinden beklentilerini ortaya çıkaracak sorular sorulmuștur. Mülakatlara uygulanan nitel içerik analizi sonucunda firmaların büyüme kararlarında tedarikçilerinden beklentilerinin öncelikli olarak ürünlerin kalitesi, maliyeti ve zamanında teslimi olduğu görülmüştür. Firmaların sadece bir tanesi uluslararasılaşma kararında tedarikçisinden maliyet konusunda beklentisi olduğunu güçlü bir șekilde belirtmiștir. Sonuç olarak, firmaların büyüme kararlarında genel olarak geleneksel/rekabetçi bir yaklaşımları olduğu; uluslararasılaşma eğilimleri düşük olduğu için bu konuda tedarikçilere önemli görev yüklemedikleri görülmüştür.

Anahtar Kelimeler: Tedarikçi, büyüme, uluslararasılaşma, nitel içerik analizi 


\section{Competition Or Cooperation: A Qualitative Study About The Firms' Expectations From Their Suppliers On Their Growth And Internationalization Decisions}

\section{Prof. Dr. Recai Coşkun ${ }^{1 *}$ Kevser Sancaktutan ${ }^{2}$}

First received: 28.12 .2018 Accepted: 09.01.2019

\section{Citation:}

Journal of the International Scientific Research (IBAD)

Volume: $4 \quad$ Issue: 1

Pages: 21-33 Year: 2019

Session: Winter

This article was checked by Turnitin. Similarity Index 01\%

\footnotetext{
${ }^{1}$ İzmir Bakırçay University, Turkey, recai.coskun@bakircay.edu.tr ORCID ID 0000-0002-5200-6098

${ }^{2}$ Sakarya University, Turkey, kevsersancaktutan@gmail.com ORCID ID 0000-0002-5649-1844

* Corresponding Author
}

\begin{abstract}
This study was conducted to determine firms' expectations from the suppliers for their growth and internationalization decisions and whether they adopt a traditional/competitive or a collaborative approach in such a relationship. This study is designed as a qualitative research where seven managers were interviewed and they were asked questions to find out the firm expectations from its suppliers. According to the result of the qualitative content analysis applied to the interviews, it was seen that in the growth decisions of the firms, the expectations from the suppliers were primarily quality, cost and timely delivery of the products they supply. Only one firm strongly underlined its cost advantage expectation from the suppliers for its internationalization decision. As a result, it is seen that firms generally have a traditionalist/competitive approach with their suppliers to their growth decisions; and since their internationalization tendency is low, they do not attain an important role to their suppliers in this issue.
\end{abstract}

Keywords: Suppliers, growth internationalization, qualitative content analysis 


\section{GíRiş}

Firmalar amaçlarına ulaşmak, rekabet üstünlügü sağlamak ve bu üstünlügü koruyup geliştirmek için bir dizi stratejik seçenek geliştirip uygulamaktadırlar. Bunların başında büyüme ve uluslararasılaşma ile ilgili olanları gelmektedir. Bu stratejiler sayesinde firmalar pazar paylarını artırıp optimal büyüklüğe ulaşarak karlılıklarını artırmayı ve ölçek ekonomisi ile maliyet üstünlüğü elde etmeyi hedeflemektedirler. Büyüme süreci ise, hem ulusal hem de uluslararası pazarları değerlendirmeyi gerektiren stratejik bir seçenektir. Doymuş ulusal pazarlardan yeni uluslararası pazarlara açılmak ve bu sayede pazar çeşitlemesi yoluna giderek riskleri yaymak firmalar için giderek daha önemli bir stratejik seçenek haline gelmekte ve uluslararasılaşan firma sayısı da buna bağlı olarak artmaktadır. Bu çalışma yukarıdaki tespitlerden hareketle büyüme ve uluslararasılaşma stratejilerini odaklanmaktadır.

Firmalar büyüme ve uluslararasılaşma stratejilerini sürdürülebilir rekabet üstünlügü oluşturabilmek için gerçekleştirirler. Bu stratejilerin başarısı iç ve dış çevresel etmenler tarafından doğrudan ya da dolaylı olarak etkilenir. $\mathrm{Bu}$ etmenlerden önemli bir tanesi, firmalara girdi sağlayan tedarikçilerdir. Tedarikçiler, ana firmalara ham maddeden ileri düzeyde işlenmiş mamullere ve hizmetlere varan girdiler sağlarlar. Girdilerin kritikliği, hacmi, bulunurluğu, tedarikçi sayısı gibi birçok öge, tedarikçi ile ana firma arasındaki ilişkinin niteliğini belirler. Ama her koşulda firmanın faaliyet alanının bir sınırı vardır ve bu sınırlar dışında kalan şeyleri tedarikçi işletmelerden temin ederler. Bu yönüyle ana firmaların büyümeleri ve uluslararasılaşmaları belli oranda tedarikçilerin bir fonksiyonudur. Bu saptamaya bağlı olarak çalışmanın amacı, yazında yeterince ele alınmayan bir konu olan, firmaların büyüme ve uluslararasılaşmalarında tedarikçilerin rolünü ortaya koymaktır.

Teknolojik, siyasi ve yönetimsel gelişmelere bağlı olarak üretim faaliyetlerinin dünya geneline yayılması ve hemen her ülkenin küresel ekonomik faaliyetlere belli düzeyde katk1 verir konuma gelmesi sonucunda, üretim süreçleri birçok aşamalara bölünmüştür. Buna bağlı olarak da tedarikçiler ile ana firma arasındaki ilişkiler stratejik bir nitelik kazanmıştır. Bu durumda firmaların iki temel stratejik karar alanı olarak büyümeleri ve uluslararasılaşmalarında tedarikçilerin rolüne ilişkin farklı yöntemlerle yürütülecek araştırmalar hem kuramsal hem de pratik açıdan ilgili literatüre anlamlı katkılar yapabilecektir.

Firma-tedarikçi ilişkisinin stratejik kararlara olan etkisinde bir diğer önemli belirleyici ise bu ilişkinin oturduğu eksenin geleneksel/rekabetçi mi yoksa işbirlikçi mi olduğudur. Özellikle 1990'lardan itibaren Japonya kökenli bazı yönetim uygulamalarının Batılı üreticiler tarafından da uyarlanması ile firmatedarikçi ilişkileri geleneksel/rekabetçi eksenden "stratejik ortak" ve işbirlikçi bir yaklaşıma doğru kaymaya başlamıştır. İşbirlikçi yaklaşım firmanın tedarikçi ile olan ilişkisinde sadece maliyet, miktar, standart, zamanında teslimat gibi geleneksel beklentileri değil, birlikte öğrenmek, sosyal ağlar oluşturup kullanmak, stratejik kararlar için geri bildirimler almak gibi çok daha geniş ve uzun soluklu bir ilişkiyi öngörmektedir. Çalışmada ayrıca bu konuyla ilgili bazı değerlendirmeler de yapılacaktır.

Çalışmada öncelikle büyüme ve uluslararasılaşma stratejilerinde tedarikçilerin rolüne ilişkin yazın incelemesi yapılacaktır. Sonrasında firma-tedarikçi ilişkisinde geleneksel ve işbirlikçi yaklaşımlar tartışlacaktır. Ardından araştırmanın tasarımı ve yürütülmesine ilişkin açıklamalar yapılacaktır. Çalışmanın bulguları ve bunlardan elde edilen çıkarımlar tartışıldıktan sonra sonuç ve öneriler sunulacaktır.

\section{FIRMA-TEDARIKÇİ İLIŞKISINININ STRATEJIK ÖNEMI}

Firmalar stratejilerini belirlerken makro, endüstri ve mikro düzeyde çevresel faktörleri dikkate almak zorundadırlar. Endüstri düzeyinde firma stratejilerinin belirlenmesi aşaması için bir çevre analiz modeli oluşturan Porter (1979: 140-141) çalışmasında tedarikçiler ile ana firma arasındaki etkileşimine ilişkin açıklamalara da yer vermektedir. Porter (1990:79-86 aynı zamanda ulusların rekabet üstünlügünün belirleyicilerini ortaya koyduğu "elmas modelinde" birbirleriyle "ilişkili ve destekleyici endüstrilerin" yani tedarikçilerin varlığının firmalar, dolayısıyla da ulusların rekabet üstünlüğü açısından önemini vurgulamaktadır. 
Tedarikçilerin varlığı, çeşitliliği, becerileri ve yetkinlikleri girdi temin ettikleri firmalara ulusal ve uluslararası düzeyde rekabet gücü kazandırır. Tedarikçilerin ana firmalara girdileri görece düşük fiyat yeterli miktar, kalite ve zamanında ulaştırırlar. Tedarikçiler ilişkide oldukları firmalara yenilik ve gelişim yönünden de katkılar sağlar ve mesafe avantajına dayalı olarak ana firmalarla bilgi akışı ve fikir alışverişi içinde olurlar. Bu sayede ana firmaların ar-ge ve yenilikçilik etkinliklerine katkıda bulunurlar. $\mathrm{Bu}$ etkileşim çift yönlüdür. Firma tedarikçisine geri bildirimde bulunur ve birlikte öğrenme ortamı oluştururlar. Büyük firmalar tedarikçilerine işbirlikçi bir yaklaşımla katkılar verirlerken aynı zamanda eğitim-geliştirme destekleri sağlayıp yenilikçilik yeteneklerini de geliştirirler (Porter, 2010:222). Denebilir ki, firmaların rekabet gücü için gereksinim duyduğu girdi kalitesi, maliyeti, ürün farklılaştırma ve yenilikçilik becerileri aynı zamanda tedarikçilerinin bir işlevidir ve onlardan bağımsız düşünülemez. Bütün bu nedenlerden dolayı firma-tedarikçi ilişkisi stratejik bir eksende düşünülmek durumundadır.

Anılan gerekçelerden dolayı firmaların rekabet stratejilerinde tedarikçilere atfettikleri önem giderek artmaktadır. Buna bağlı olarak tedarikçi seçimi, tedarik zinciri yönetimi, satın alma yönetimi ve tedarikçi ilişkileri gibi konular firmalar için giderek stratejik bir önem kazanmaktadır. Firmalar esasen tedarikçilerden temin ettikleri girdilere yaptıkları katma değer nispetinde başarılı olmaktadırlar. Tedarikçilerin bu kritik önemi onlarla kurulacak ilişkinin stratejik değerini de ortaya koymaktadır. Tedarikçi ilişkisi konusunda gösterilecek başarı firmaların finansal göstergelerine ve dolayısıyla rekabet güçlerine de olumlu biçimde yansıyacaktır (Weele, 2014: 3). Tedarikçilerin ve tedarikçi ilişkilerinin bu önemi, satın alma yönetiminin de stratejik bir konuma gelmesine neden olmuştur. Weele'nin (2014:11) satın alma yönetimini "tedarikçilerle olan ilişkileri ve tedarikçilerin faaliyetlerini firmanın stratejileriyle uyumlaştırma çalışmaları" biçiminde tanımladığını da not düşmek gerekir.

\section{FIRMA-TEDARIKÇ̧i İLIŞKISINIDE REKABETÇI VE İŞBİRLIKÇİ YAKLAŞIMLAR}

Firmaların tedarikçileriyle ilişkilerinde iletişim düzeyi, tedarikçi seçimindeki kıstaslar, birbirlerine bağl1lık düzeyleri, ilişkinin genişliği ve uzunluğu gibi ölçütler dikkate alınarak oluşturulan farklı modellerden söz edilmektedir (Olalla et al., 2010:3492). Ancak bunları iki ana başlık altında toplamak mümkündür: Geleneksel/Rekabetçi ve İşbirlikçi modeller. Şüphesiz modellerin adlandırılmasında da farklı1ıklar görülmektedir. Geleneksel/Rekabetçi modelde uzun dönemli bir işbirliği ve bilgi paylaşımı öngörülmez. Tedarikçi seçiminde ana ölçüt satın alınacak ürünlerin fiyatıdır. Taraflar arasındaki etkileşim asgari düzeydedir. Firma çok sayıda tedarikçiyle görece kısa dönemli sözleşme imzalamak eğilimindedir. Sözleşmede fiyat, kalite, teslimat ve ödeme koşullarına yer verilir. Taraflar mümkün olduğunca birbirlerinden bağımsız kalmaya dikkat ettiğinden, aralarındaki bilgi paylaşımı genellikle sözleşmeye konu edilen ürünlerin özellikleriyle sınırlıdır (Olalla et al., 2010:3492).

Bir genelleme yapılacak olursa, Batıda rekabetçi, Doğuda ise işbirlikçi yaklaşımın öncelendiği söylenebilir (Güleş ve Burgess, 1996; Güleş, 1999a:48). Ancak işbirliğine dayalı ilişkilerin önemi giderek anlaşılmaya başlamıştır. Örneğin kimi İngiliz üreticileri kaybetmeye başladıkları küresel rekabet üstünlüklerini tekrar elde etmek için çıkış yolu olarak tedarikçileriyle kurdukları rekabetçi ilişkileri işbirlikçi bir zemine taşımayı bulmuşlardır (Morris ve Imrie, 1992:10; akt. Güleş, 1999b: 3). Bu ilişkide firmaların temel amacı, satın aldıkları girdilerin fiyatlarını düşürmektir. Dolayısıyla rekabetçi ilişkide fiyat dışında bir işbirliği katkısı da beklenmez. Tedarikçi-ana firma arasındaki iletişim de fiyat ve diğer rutinlerle sınırlı kalır, diğer alanlarda bilgi akışı gerçekleşmez (Shapiro, 1986: 1-5).

Firma-tedarikçi ilişkisinde işbirlikçi yaklaşımda firma tedarikçilerini seçerken çok daha dikkatli davranır. Hem operasyonel hem de stratejik ölçütler dikkate alınırken taraflar arasındaki etkileşim çok daha geniş bir alanı kapsar. İlişkiler açısından uzun vadeli, üretim, tasarım, inovasyon gibi alanlarda yakın ve güven üzerine kurulmuş bir işbirliği söz konusudur. Tedarikçi sayısı mümkün olduğunca düşük tutulur (Olalla et al., 2010:3492-3). Tarafların karş1lıklı olarak birbirlerini besledikleri bu yaklaşım sonucunda uzun dönemde rekabet üstünlügünü getirecek nitelikte ürünler ve maliyet avantaj1 sağlanmış olur. Taraflar arasında kurulan iletişim farklı alanlarda ve güçlü bir şekilde, karşılıklı saygıya ve güvene dayalı olarak işlemektedir (Shapiro, 1986; Olalla et al., 2010: 3493). Bu iki yaklaşım dikkate alındığında firmatedarikçi ilişkisinde işbirlikçi modeli benimseyenlerin büyüme ve uluslararasılaşma bakımından da avantajlı olacakları varsayılabilir. Çünkü az sayıda tedarikçi ile birlikte öğrenmeye, güvene ve saygıya dayalı geniş çerçeveli ve uzun bir işbirliği doğal olarak çok sayıda tedarikçi ile dar kapsamlı ve kısa 
dönemli ve de sözleşmelerle sınırlı iş yapan firmalara göre çok daha az işlem maliyeti ve belirsizlik anlamına gelecektir. Böylece sözleşmelerden kaynaklanan maliyetler azalacak, uzun dönemli gerçekleştirilecek işbirliği bir sinerji oluşturacak, tüm bunlarda birlikte öğrenme ve uygulamadan kaynaklı üstünlükleri besleyecektir.

\section{FIRMALARIN BÜYÜME VE ULUSLARARASILAŞMA STRATEJILERINDE TEDARÍKÇILERIN ROLÜ}

Firmalar, tanımları gereği büyüme eğilimindedirler ve büyüme stratejileri de bu nedenle Stratejik Yönetimin önemli konularından birisidir (Rothaermel, 2015:294). Ancak bu durum her firma için büyümenin kaçınılmaz veya karşı konulmaz bir olgu olduğu anlamına gelmez. Görece az sayıda da olsa bazı firmalar büyümeye karşı koşullar elverişli olsa da kayıtsız kalabilmektedirler (Coad, 2009:111). Ancak, görgül veriler firmalar yaşlandıkça büyüdükleri şeklinde bir genellemeye imkân tanımaktadır. Burada büyüme ölçütü olarak çalışan sayısından sermayeye, yıllık hasılattan üretim miktarına varan değişik ölçütler kullanılmaktadır. Firmalar aynı zamanda ortalamanın üzerinde bir performans gösterip varlıklarını sürdürmek ve rekabet üstünlüğü elde edebilmek adına farklı büyüme stratejileri geliştirirler (Dinçer, 1996; Rothaermel, 2015; Ülgen ve Mirze, 2004). Büyüme sayesinde ölçek ve kapsam ekonomileri gibi somut kazançların yanında büyüklükten kaynaklanan itibar ve rakiplerden görülen sayg1 gibi psikolojik edinimlerden de söz edilebilir (Coad, 2009:112). Bu büyüklügün ne olmas1 gerektiği firma teorisi alanında önemli tartışmalardan birisidir. Penrose (2009:79) "büyüklük ekonomisi” kavramını "firmanın daha küçük firmalara göre yalnızca büyüklügünden kaynaklanan üstünlük sayesinde, sadece ürün ve hizmetleri daha etkin üretip satmakla kalmayıp aynı zamanda yeni ürünleri veya daha büyük miktarda üretimi de daha etkin olarak gerçekleştirebilme becerisi” şeklinde tanımlamaktadır. Ancak böyle bir durumda büyüklükten kaynaklı üstünlüklerden söz etmek mümkündür.

Büyüme seçeneği yalnızca iç pazarla sınırlı değildir. Uluslararasılaşma girişimleri de bir büyüme seçeneğidir ve son yıllarda bu seçenek giderek daha fazla önem kazanmaktadır. Araştırmalar yenilikçilik ile uluslararasılaşmanın baş başa gittiklerini, en başarılı büyüme seçeneklerinden bir tanesinin yenilikçilik ile uluslararasılaşma karması olduğunu göstermektedir (Kylaheiko et al., 2011:511-516; Osuna, 2014: 80-81; Ruzzier et al., 2013:591).

Firmaların büyüme ve uluslararasılaşma kararlarında dikkate aldıkları önemli değişkenlerden bir tanesi de tedarikçilerdir. Hatta bazı durumlarda firmalar sırf tedarikçilerine yakın olmak amacıyla da uluslararasılaşabilmektedirler (Coşkun vd., 2016:47). Dolayısıyla tedarikçiler firmaların büyüme ve uluslararasılaşma süreçlerini doğrudan veya dolaylı olarak etkileyebilirler. Firmanın çevresinde yeterli sayıda ve nitelikte tedarikçilerin bulunması stratejik karar ve uygulamalarının başarısı için bir ön koşuldur. Ayrıca yenilikçilik faaliyetleri için de tedarikçilerle etkin işbirliği gereklidir. Yenilikçilik aynı zamanda firmanın büyüme ve uluslararasılaşma girişimlerine katkı yapmaktadır (Kylaheiko et al., 2011:511-516; Karaöz ve Demirgil, 2009:60-61; Demirgil, 2008:116). Büyüme stratejileri kapsamında yürütülecek ürün farklılaştırma ve çeşitlendirme çalışmalarında da yenilikçilik ve dolayısıyla tedarikçi katkısı gerekecektir. Tedarikçilerle kurulan iyi bir iletişim sonrasında yeni ürün fikirleri, yeni tasarımlar, ürün ve süreç iyileştirme gibi konularda değerli girdiler elde etmek mümkün olabilecektir (Weele, 2014:bl.9; Bedir, 2009:174-177). Yine bir uluslararasılaşma modeli olarak Johanson ve Vahlne'nin (1990:18-20) öne sürdüğü ağ modelinde, firmaların ağ sisteminde bulunan tedarikçilerden pazar bilgisi edinerek uluslararası pazarlara açılmalarının mümkün olduğu belirtilmektedir. Bu konu Porter'in (1990:82-83) elmas modelinde de ele alınmış ve tedarikçilerin ana endüstrilerin inovasyon ve iyileştirme çalışmalarına katkıları tartışılmıştır.

\section{ARAŞTIRMANIN YÖNTEMİ, TASARIMI VE VERILLERI}

Yukarıdaki yazın incelemesi göstermektedir ki, firma-tedarikçi ilişkisini konu edinen çalışmalara rastlansa da bu ilişkiyi büyüme ve uluslararasılaşma odaklı olarak inceleyen ve özellikle Türkiye bağlamını "rekabetçilik-işbirlikçilik" mantığıyla sorgulayan çalışmalar kısıtlı sayıdadır. Bu araştırma, sözü edilen alana katkı yapmayı amaçlamaktadır. 
Çalışma iki araştırma sorusuna yanıt bulmak üzere tasarlanmıştır:

a) Firmanın büyüme ve uluslararasılaşma kararlarında tedarikçilerinden beklentileri nelerdir?

b) Firma-tedarikçi ilişkisi rekabetçi mi yoksa işbirlikçi bir yaklaşımla mı biçimlenmektedir?

Çalışma, nitel araştırma olarak tasarlanmıştır. Bunun anlamı, genel kurallar ve yasalar aramaktan çok, ele alınan olgunun işleyiş̧ini "anlamaya" yönelik bir araştırma süreci izlemektir. Buna bağlı olarak da yorumlamacı yaklaşım benimsenmiştir. Genel geçer kural arayışından çok, ele alınan olgu ve gözlem birimlerinin kendine özgülükleri incelemeye konu edilmiştir. Gözlem birimi olarak firmaları temsilen yöneticiler belirlenmiştir. Firmalar seçilirken de yoğun tedarikçi ilişkisinde olmaları öncelikli ölçüt olarak dikkate alınmıştır.

Tedarikçi-ana firma iliş̧isini sorgularken sınırlı sayıda kişiyle görüşme yapılabilmesi ve iletişime geçilen yöneticilerin veri ve bilgileri paylaşma konusundaki gönülsüzlükleri, araştırmanın veri edinme sürecini "yarı biçimlendirilmiş görüşme" tekniği ile yürütmeyi zorunlu kılmıştır. Mülakat soruları oluşturulduktan sonra, bir başka uzman tarafından da incelenmiş ve son biçimini almıştır. Görüşme sırasında yanlış veya farklı anlamaları ortadan kaldıracak açıklamalar ve yeni soru-cevaplar ile süreç tamamlanmıştır. Bu çerçevede daha önce iletişim kurulan sekiz firmanın fabrika müdürleri veya satın alma yöneticilerine görüşme talebi iletilmiştir. Bunlardan beşi ile yüz yüze görüşülmüsstür. Diğer üç firma yetkilisi ise yüz yüze görüşme yerine, soruları -posta yoluyla cevaplamayı tercih etmişlerdir. Bu aşamada görüşüne başvurulan yöneticilerden bir tanesi sorulara eksik cevaplar vermiştir. Sonuç olarak beş yönetici ile yarı biçimsel, ikisi ile de biçimsel görüşme yapılarak toplam yedi firma çalışmaya konu edilmiştir. Firmaların üçü Kocaeli'nde, üçü İstanbul'da, biri de Sakarya'da faaliyet göstermektedir. Faaliyet alanları ise gıda, trafo komponentleri, ambalaj, temizlik ürünleri, ilaç sanayi, kablo sanayi ve tekstildir.

Görüşmeler metne dönüştürülmüş ve MAXQDA programıyla nitel içerik çözümlemesine tabi tutulmuştur. Nitel içerik çözümlemesinde amaç, ele alınan olguya ilişkin metin içinde bulunan anlamları belli bir düzen oluşturacak biçimde ortaya çıkarmak ve sonrasında olguya ilişkin belli yorumlar yapabilmektir. Nicel içerik çözümlemesinde belli kelime ve kavramların istatistiksel olarak ortaya konması amaçlanırken, nitel çözümlemede kavramların sayısallaştırılmasından özellikle kaçınılır. Aranan anlamdır, olgunun işleyişini kavramların ortaya çıkışından hareketle yorumlamaktır. Bunun için öncelikle yazından hareketle kodlamalar ve boyutlar oluşturulur. Kodlamalarda her zaman bir ihtiyarilik vardır. O nedenle metin defalarca okunur ve kodlar/etiketler ve boyutlar uzmanlarla tartış1lır. Eğer yazında yer almayan durumlar ortaya çıkarsa bunlar da kodlama sistemine dâhil edilir. Yazında sözü edilmeyen durumların ortaya çıkması çalışmanın özgünlüğünün ve incelemeye konu edilen birimdeki durumun kendine özgü oluşundan kaynaklanabilir. $\mathrm{Bu}$ da incelenen birimlerin iyi seçildiğinin göstergesidir. Ancak kimi zaman böylesi bir durum yapılan yazın incelemesinin eksikliğinden, etiketlemede yeterince özen gösterilmemesinden ve ifadelerin farklı yorumlanmasından kaynaklı olabilir.

\section{Araştırmanın Güvenvericiliği (Trustworthiness)}

Şemsiye bir kavram olarak nitel araştırmaların kalitesini güvence altına almaya çalışan güvenvericilik (Trustworthiness) nicel araştırmalardaki genellenebilirlik, geçerlik, güvenirlik ve nesnellik arayışının tam karşılıkları değildir. Ancak pozitivist bakış açısıyla yorumlamacılığa getirilen eleştirilere karşılık nitel araştırmaların da belli "bilimsellik" kaygısı taşıdığının göstergesi olarak çalışmanın inandırıcılığı, aktarılabilirliği, onanabilirliği güvence altına alınır (Coşkun, 2017:6). Yukarıda ifade edildiği gibi çalışma nitel olarak tasarlandığı için genelleme kaygısı yerine bir durumu ortaya koymak, açıklama kaygısı yerine ise anlamaya çalışmak odaklı bir süreç izlenmiştir. Sürecin her aşamasında "uzman görüşü" alınmıştır. Buna ek olarak, araştırmacılar çalışmanın her aşamasında öz değerlendirme ve özeleştiri ile süreçlerin üzerinden tekrar geçmişlerdir. Bulguların yorumlanmasında nötrlük/yansızlık kaygıs1 güdülmüş, benzeri bulguların farklı araştırmacılar tarafindan benzeri şekilde yorumlanacağı temin edilmeye çalışılmıştır. Metinler farklı kişilerin görüşüne sunulmuştur. Çalışmanın benzeri tasarımla başka konu ve alanlara da uygulanabileceği öngörülmüştür. Bulgularının hem alan hem de ilgili alanlar için kuramsal ve pratik katkı yapabileceği düşünülmektedir. Yeri geldiğince izlenen süreçlere ilişkin gerekli açıklamalar yapılmıştır. 


\section{Verilerin Kodlanması}

Öncelikli olarak görüşmeler metne dönüştürülmüş ve MAXQDA programında çözümlemeye hazır duruma getirilmiştir. Bunun için ilkin program üzerinde çeşitli kodlar oluşturulmuştur. $\mathrm{Bu}$ kodlar, araştırma soruları ve yukarıda incelenen çalışmalar temel alınarak belirlenmiştir. Ayrıca açık kodlar (in vivo coding) da oluşturulmuştur. Açık kodlar literatürde rastlamayıp da mülakatlar sonucunda ortaya çıkmıştır. Mülakatta yöneticilere "Tedarikçi işletmelerin firmanızın büyümesinde katkısı olduğunu düşünüyor musunuz? Nasıl?", "Firmanızın büyüme stratejilerini belirlerken tedarikçilere ne gibi roller düşüyor? Onlara sorumluluklar yüklüyor musunuz?" "Uluslararasılaşma sürecinizde tedarikçilerin rolü olduğunu düşünüyor musunuz? Nasıl?" örneklerinde olduğu gibi "açık uçlu" sorular yöneltilmiştir. Tablo 1'de tedarikçilerin büyüme üzerindeki, Tablo 2'de ise uluslararasılaşma üzerindeki rollerini temsil eden kodlar verilmiştir.

\begin{tabular}{c}
\hline Tablo 1: Tedarikçilerin Büyüme Kararı Üzerindeki Roller \\
Yenilik Faaliyetlerine Katkı \\
Maliyet \\
Temel Yeteneklere Odaklanma \\
Zamanında Teslimat \\
Kalite \\
Üretim Sisteminde İyileştirmeler \\
Bilgi Paylaşımı \\
Hız \\
Esneklik \\
Teknik Destek (in vivo) \\
Kesintisiz Hizmet (in vivo) \\
Üretim Kapasitelerinin Yeterliliği (in vivo) \\
Standardı Sağlama (in vivo)
\end{tabular}

Tablo 2. Tedarikçilerin Uluslararasılaşma Kararı Üzerindeki Rolleri

Maliyet Avantaj1

Pazar Bilgisi Edinme

Kalite (in vivo)

Kesintisiz Tedarik Yapma (in vivo)

\section{BULGULAR VE YORUM}

\section{Firmaların Büyüme Stratejilerinde Tedarikçilerden Beklentileri: Genel Çıkarımlar ve Değerlendirme}

Firma yöneticileri ile gerçekleştirilen mülakatlar sonucunda elde edilen veriler MAXQDA programı kullanılarak çözümlenmiştir. Tablo 3 her bir firmanın büyüme ve uluslararasılaşmasında tedarikçilerinden ne tür beklentileri olduğunu göstermektedir. Her bir daire, ilgili firmanın o alanda katkısını, dairelerin büyüklügü ise yapılan katkının firma için taşıdığı önemi göstermektedir. 
Tablo 3. İçerik Çözümlemesi Sonuçlarının Genel Dökümü

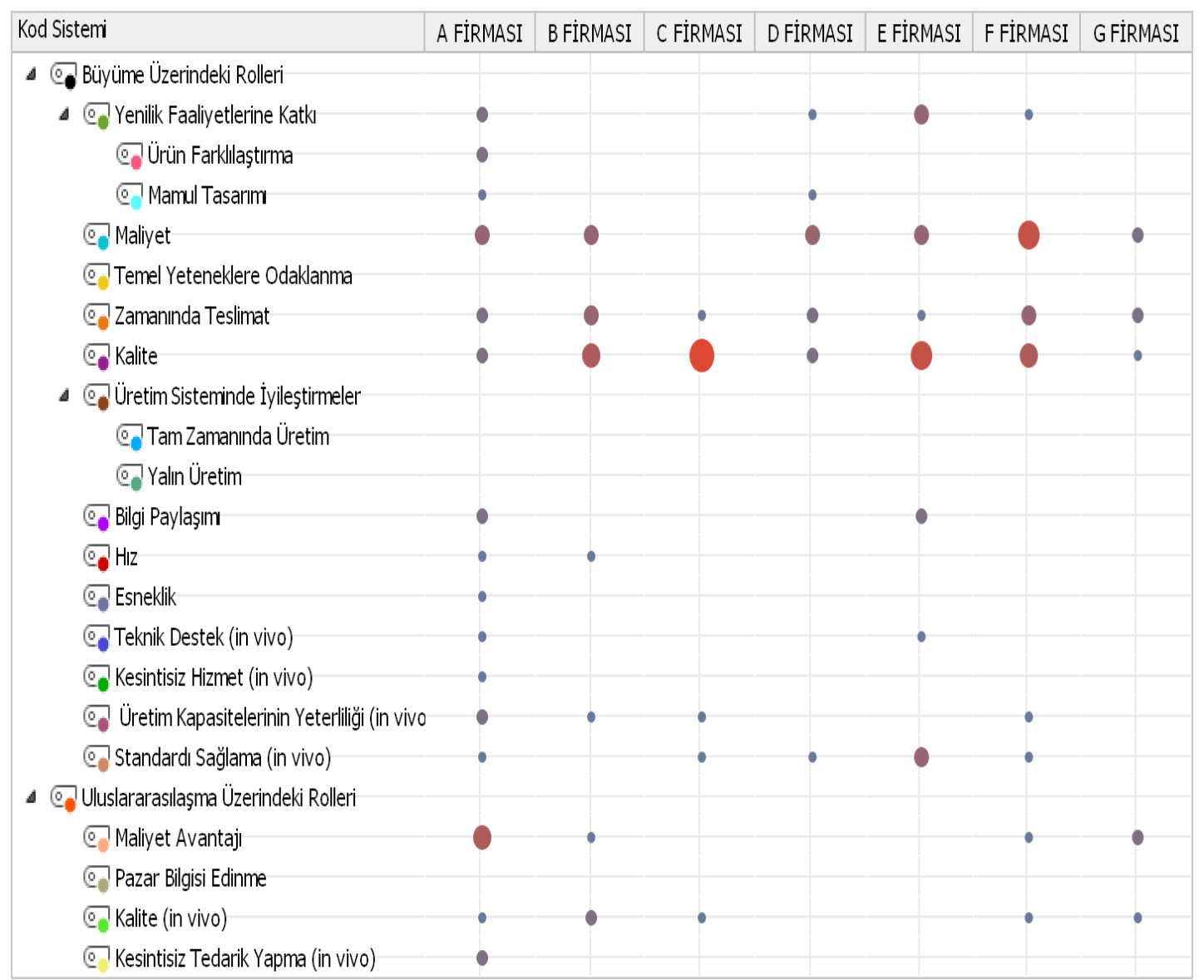

Görüldüğü gibi her firma büyümede ve uluslararasılaşma sürecinde tedarikçilere farklı roller yüklemekte ve farklı beklentilere girmektedir. Konuya "büyüme" açısından bakacak olursak şu çıkarımları yapmak mümkündür:

a) Kalite kaygısının bütün firmalar için öncelikli olduğu açıkça görülmektedir. C firması ise kaliteye özel bir önem atfetmekte, tedarikçilerden öncelikli beklentisinin kalite olduğunu vurgulamaktadır. Aynı şekilde sırasıyla E, F ve B firmalarının da tedarikçi ilişkilerinde kaliteye özel bir önem atfettikleri görülmektedir. Bu durum özellikle F firması için geçerlidir.

b) Bütün firmaların tedarikçilerinden bekledikleri bir diğer işlev ise zamanında teslimattır. Ancak bu işlev kalite kadar önemli görülmemektedir. Sadece B ve F firmaları tedarikçilerden zamanında teslimat konusunda beklentilerini görece yüksek duyarlılıkla dile getirmişlerdir.

c) C firması dışında bütün firmalar tedarikçilerini belirlerken maliyeti özel bir değişken olarak kabul etmektedirler. Maliyeti tedarikçi ilişkilerinde bir değişken olarak görmeyen sadece $\mathrm{C}$ firmasıdır. Kaliteye büyük önem veren bu firmanın maliyeti öncelememesi bu bakımdan anlaşılabilir bir durumdur.

d) Tablo 3'ten yapılabilecek önemli bir başka çıarım ise "üretim sisteminde iyileştirme" bağlamında dile getirilen "tam zamanında üretim, yalın üretim gibi yönetim ve üretim tekniklerinin “dönemsellik" gösterdiği gerçeğidir. 1990'ların sonu ile 2000'li yılların başında çokça ele alınan bu kavramlar son dönemlerde ya birer "standart uygulamaya" dönüştüler ya da yerlerini yeni yönetsel tekniklere biraktılar. Dolayısıyla yöneticilerin günlük mesleki dili içerisinde de önemlerini kaybettiler. Firma temsilcilerinin yalın ve tam zamanında üretim konusunu hiç dile getirmemelerinin bir diğer nedeni olarak bu tekniklerin uygulanmasında tedarikçilerinden herhangi bir beklentilerinin olmaması düşünülebilir. Ancak böyle bir yorum çok mantıklı olmayacaktır. Zira her iki yönetsel tekniğin uygulanabilmesi aynı zamanda tedarikçilerin de doğrudan bir fonksiyonudur. Konuyla yakında ilgili olan "temel yeteneklere 
odaklanma" da hiçbir firma için tedarikçi seçiminde belirleyici bir değişken olarak dikkate alınmamıştır. Üstteki yorumlar bu boyut için de geçerlidir. Görüşülen firmaların "temel yetkinlik" tanımlamadıkları, bu nedenle tedarikçilerinde böylesi bir beklentiye girmedikleri çıkarımı da mantıklı gözükmektedir.

Çizim 1. Firmaların Büyüme Kararlarında Tedarikçilerinden Beklentileri

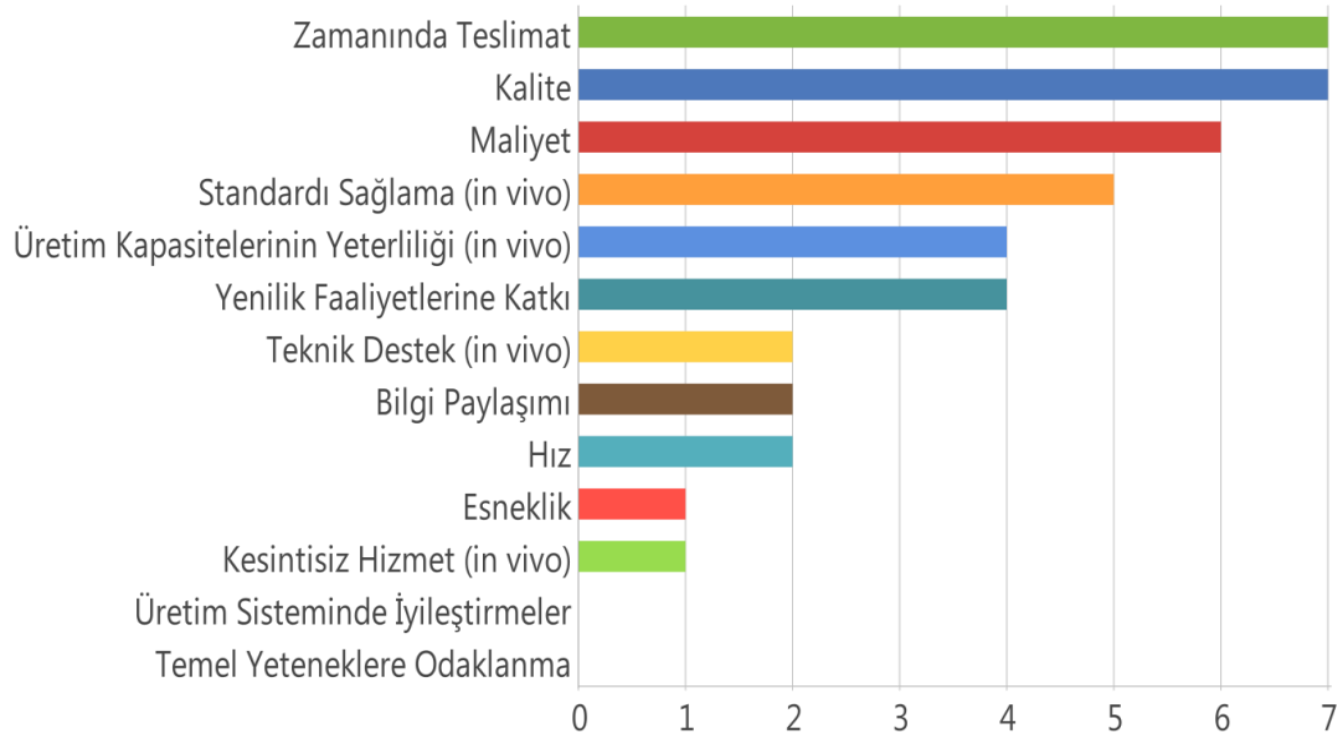

a) Her firma için ayrı ayrı bir değerlendirme yapılacak olursa, A firmasının tedarikçilerinden "her şeyden biraz" biçiminde bir beklentisi olduğu görülmektedir. Bu durum firmanın tedarikçilere stratejik bir anlam yüklemediğini göstermektedir. Aynı zamanda kendisini konumlandırmada belirgin bir yaklaşımının, bir odak noktasının olmadığı çıkarımı da yapılabilir. Bu bakımdan A firması bulduğu herhangi bir tedarikçiyle çalışabileceği izlenimini vermektedir. Buna karşılık B firması tedarikçilerinden maliyet, zamanında teslimat ve kalite konularında beklentileri olduğunu belirgin bir şekilde ortaya koymaktadır. C firması ise çok açık biçimde "kalite" odaklı bir beklentiyi dile getirmektedir. Bu firmanın büyüme stratejisinin kalite odaklı olduğu söylenebilir. D firması A firmasına benzer şekilde tedarikçilerine hiçbir konuda anlamlı bir işlev yüklememektedir. Dolayısıyla bu firma için de tedarikçilerin kritik bir önemi olmadığı çıkarımı yapılabilir. E firması büyüme stratejisinde tedarikçilerden yine kalite ve maliyet konularında önemli derecede beklentiye girerken diğer tüm firmalardan farklı olarak "yenilik faaliyetlerine katkı" değişkenini de öncelediğini belirtmektedir. F firması sırasıyla maliyet, kalite ve zamanında teslimata önem verdiğini belirgin bir şekilde vurgulamakta ve tedarikçilerden büyüme kararında bu alanlarda beklentisi olduğunu bildirmektedir. Bu durum firmanın tedarikçi seçiminde belli ölçütleri olduğunu göstermektedir. G firması da büyüme stratejisinde tedarikçilere özel bir görev yüklememekte, maliyet, zamanında teslimat gibi konuları dile getirmekle yetinmektedir.

Görüldüğü üzere, firmaları büyüme kararlarında tedarikçilerden beklentilerine göre iki gruba ayırmak doğru olacaktır. Birinci grupta C, E, F, firmaları gibi tedarikçilerden ne beklediğini belirgin bir şekilde dile getirenler; ikinci grupta ise $\mathrm{D}$ ve $\mathrm{G}$ firmaları örneğinde görüldügü üzere tedarikçilere özel bir görev yüklemeyen firmalar yer almaktadır.

\section{Firmaların Uluslararasılaşma Stratejilerinde Tedarikçilerinden Beklentileri: Genel Çıkarımlar ve Değerlendirme}

Uluslararasılaşma stratejisine özel değerlendirmelere geçmeden önce belirtmek gerekir ki, uluslararasılaşma zaten bir büyüme stratejisidir. Firmalar büyüme stratejisini oluştururken değişik seçeneklere sahiptir. Ölçek büyütebilir, ürün çeşitlendirebilir, geriye doğru bütünleşerek tedarikçilerini veya ileriye doğru bütünleşerek dağıtıcı işletmeleri bünyelerine katabilirler. Bunların yanında farklı 
endüstrilerde faaliyette bulunarak ilişkili veya ilişkisiz büyüme seçeneklerini değerlendirebilirler. Coğrafi olarak bakıldığında ise iki seçene söz konusudur. Ya ülke içinde faaliyette bulunduğu coğrafi alanları çeşitlendirecek ya da ülke sınırları dışında faaliyette bulunmaya karar vererek uluslararasılaşacaktır. $\mathrm{Bu}$ nedenle büyüme stratejilerinde tedarikçilerden beklentilerin aynı zamanda uluslararasılaşma stratejileri için de geçerli olduğu düşünülebilir. Ancak her işletmenin uluslararasılaşmaya atfettiği önem aynı düzeyde olmayacağından bu çalışmada iki olgunun ayrı başlıklar altında incelenmesi uygun görülmüştür. Ayrıca firma yöneticilerinin uluslararasılaşmada hangi değişkenlere özel önem atfettiklerini de bu ayrım sayesinde görmek mümkün olacaktır.

Uluslararasılaşma ile ilgili sorulara beş firma yöneticisi cevap vermiştir. Bu durum, diğer iki firmanın böyle bir stratejisi olmadığı olarak açıklanabilir. Çizim 2, firmaların uluslararasılaşma sürecinde tedarikçilerinden beklentilerini göstermektedir.

Çizim 2. Firmaların Uluslararasılaşma Kararlarında Tedarikçilerden Beklentileri

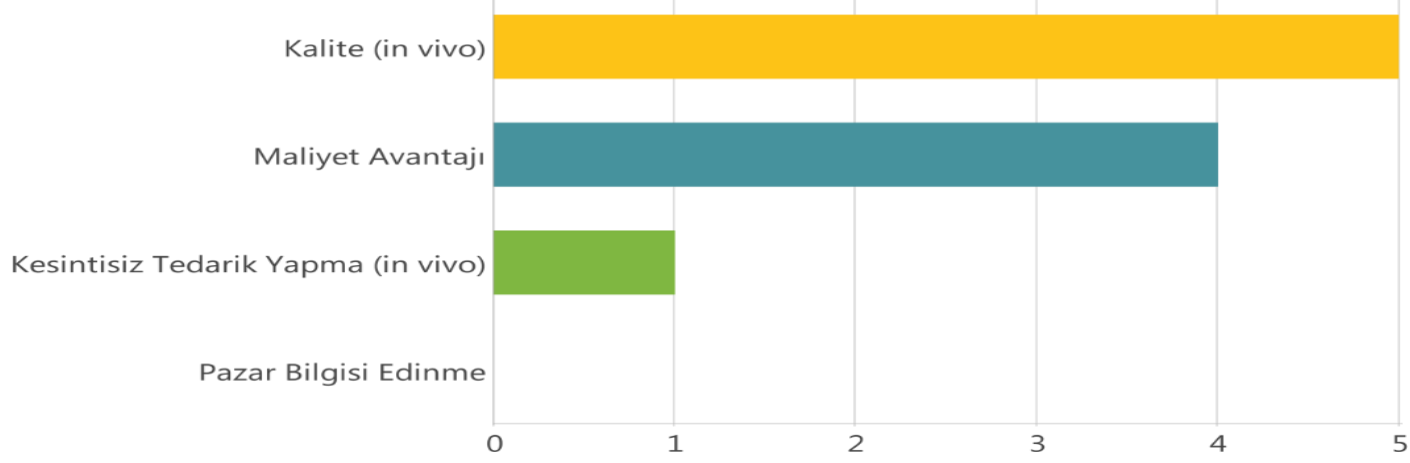

Görüldüğü üzere beş firma kalite, dört firma maliyet, bir firma kesintisiz tedarik değişkenine dikkat çekerken pazar bilgisi edinme konusunda tedarikçisinden beklentiyi dile getiren herhangi bir firma yöneticisi olmamıştır. Sadece A firması maliyet konusunu uluslararasılaşma stratejisinde önemli bir değişken olarak belirtmiştir. Bulgular, firmaların uluslararasılaşmayı önceleyen stratejilere sahip olmadığını göstermektedir. Büyüme konusunda tedarikçilerinden beklentileri çeşitlilik gösterirken uluslararasılaşmada bu durum gözlenmemektedir. Bulgular uluslararasılaşma stratejisine ilişkin daha fazla yorum yapmaya imkân tanımamaktadır. Yukarıda da belirtildiği gibi uluslararasılaşma da bir tür büyüme olduğu için firmaların büyüme konusundaki yaklaşımlarını buraya da atfetmek olanaklıdır. Ancak görülen o ki, araştırmaya dâhil edilen firma yöneticileri uluslararasılaşmaya genel büyüme stratejisi dışında özel bir anlam veya önem yüklememektedirler.

\section{Firmalar Tedarikçileriyle İlişkilerinde Rekabetçi mi, İşbirlikçi mi?}

Olguya firmanın büyüme stratejilerinde tedarikçileriyle olan ilişkisinde "rekabetçi”" mi yoksa "işbirlikçi" bir yaklaşımı mı benimsedikleri yönünden de bakmak gerekir. Bu durumda araştırmaya konu edilen firmaların ağırlıklı olarak "geleneksel-rekabetçi" yaklaşımı benimsedikleri söylenebilir. Firmalar büyüme gibi stratejik kararlarında tedarikçilerini "işbirliği yapılabilecek birer paydaş" olarak değil, piyasada kendisine potansiyel rakip olabilecek ekonomik birimler olarak görmektedirler. Örneğin "tedarikçilerle bilgi paylaşımı" gibi "işbirlikçi”" bir yaklaşımı sadece A ve F firmaları dile getirmiş ama bu firmalar da bu beklentiye özel bir önem atfetmemişlerdir. Yine sadece E firması "yenilik faaliyetlerine katkı" konusunda tedarikçilerinden beklentisi olduğunu önemle vurgulamış, bunun dışında A, D, F, firmaları ise konuya özel bir anlam yüklemeden değinmişlerdir.

Oysa maliyet, kalite, zamanında teslimat, standartların sağlanması gibi geleneksel-rekabetçi tedarikçi ilişkisini gösteren konuları firmaların çok daha fazla öne çıkardıkları görülmektedir. Dolayısıyla firmatedarikçi ilişkisinde rekabetçi yaklaşımın benimsendiğini söylemek mümkündür. Bu durumu Türk sanayinin gelişmişlik düzeyi ile açıklanabilir. Yeterli bilgi ve tecrübe birikiminin olmadığı, tedarikçilerin 
süreçte oynayabilecekleri kritik rolün anlaşılamadığı bu aşamada, yeni yönetim yaklaşımlarının uygulamaya geçirilmesi de güç olmaktadır.

Büyüme ile ilgili olarak literatürde rastlanmayıp da bu çalışmada öne çıkan kesintisiz hizmet, teknik destek, standart sağlama gibi boyutların yeterince araştırılmamış olması, bu alanda Türkiye'de yapılan çalışmaların sayısal anlamda yetersizliğini de ortaya koymaktadır.

\section{SONUÇ VE ÖNERILER}

Bulgular 1şı̆̆ında şu sonuçlara ulaşılmıştır:

a) Firmalar büyüme stratejilerinde tedarikçilerinden beklentilerini maliyet, kalite, zamanında teslimat gibi geleneksel tedarikçi ilişkisi üzerine oturtmuşlardır.

b) İncelenen firmaların uluslararasılaşmayı stratejik bir seçenek olarak belirlediklerine ilişkin güçlü bulgulara rastlanmamıştır. Sadece bir firma uluslararasılaşma için maliyet üstünlüğ̈̈ sağlayabilecek tedarikçilere gerek duyduğunu güçlü bir şekilde vurgulamıştır.

c) Firma-tedarikçi ilişkisinde geleneksel/rekabetçi yaklaşımın öngördüğ̈̈ biçimde "maliyet, kalite, zamanında teslim" ekseninde biçimlenen bir anlayış hâkimdir. Bu durum, tedarikçiyi "stratejik bir ortak" olarak görme ve onunla uzun dönemli bir işbirliği geliştirip birlikte öğrenme ve gelişme anlayışının henüz oluşmadığına işaret etmektedir.

d) Dönemsel olarak öne çıkan moda niteliğindeki yönetsel yaklaşımların uzun dönemde firmalara yapabileceği fazla bir katkının olmadığı, 2000'li yılların başında dillerden düşmeyen birçok kavramın giderek önemini kaybetmesinden anlaşılmaktadır. Bunun yerine hem üretimde yapısal dönüşümü, hem de üretici-tedarikçi ilişkilerinde kalıcı işbirliği anlayışını geliştirebilecek alanlara öncelik verilmelidir.

e) Firmalar için uluslararasılaşma eğiliminin hala düşük olduğu görülmektedir. Türkiye'nin 1980'li yıllardan günümüze istikrarlı bir şekilde takip ettiği dişa açık büyüme modeline ve çevre ülkelerle ekonomik ilişkilerde yaşanan ilerlemelere rağmen Türk firmalarının uluslararası pazarlara açılma eğilimlerinin hala yeterli düzeyde olmadığı söylenebilir. Bu çıkarım sadece bu çalışma çerçevesinde görüşülen firma yöneticilerinin söylediklerine dayalı olarak yapılmamaktadır. Makroekonomik göstergeler, endüstri ve firma düzeyinde veriler bu duruma işaret etmektedir.

$\mathrm{Bu}$ çalışmanın ortaya koyduğu bir başka husus, firma-tedarikçi ilişkisinin niteliği ve bu ilişkide benimsenen yaklaşımlar konusunda yeterince çalışma yapılmadığıdır. Alanda önemli bir boşluk vardır. Farklı endüstrilerde bu bağlamda yapılacak çalışmalar bu ilişkinin stratejik bir mahiyet kazanamamasından doğan sakıncaları firmaların büyümesi ve uluslararasılaşması bağlamında ortaya koyacaktır. Ayrıca firma-tedarikçi ilişkilerinin uzun dönemli stratejik bir nitelik kazandığı örnek olayların ortaya konması ve bu durumda her iki tarafın elde edebileceği avantajların tartışılması firmaların rekabet güçlerine katkı yapacaktır.

Bilgilendirme / Acknowledgement: $\mathrm{Bu}$ çalışma Kevser Sancaktutan tarafindan Sakarya Üniversitesi İşletme Enstitüsünde Prof. Dr. Recai Coşkun danışmanlığında yürütülen "Ana Endüstrilerin Büyümesinde ve Uluslararasılaşma Sürecinde Destekleyici Endüstrilerin Rolü: Seçilmiş Firmalar Üzerinden Bir Çözümleme” başlıklı ve Mayıs 2018 tarihli yüksek lisans tezinden türetilmiştir.

\section{KAYNAKÇA}

Bedir, A. (2009). Uluslararasl ticarette fiyata dayalı rekabet gücü ile endüstri-içi ticaret arasındaki ilişki: Türk imalat sanayi örneği. Yayımlanmamış Doktora Tezi, Ankara Üniversitesi Sosyal Bilimler Enstitüsü, Ankara.

Coad, A. (2009) The growth of firms: A survey of theories and empirical evidence. Edward Elgar Publishing.

Coşkun, R. (2017). Yönetim organizasyon kitaplarında klasik yönetime atfedilen 'kapalı sistem' yaklaşımına itiraz: 1925 yılından önce yazılmış seçilmiş kitaplarda 'açık sistem' imaları üzerine 
nitel bir çözümleme. 8. Uluslararası Balkanlarda Sosyal Bilimler Kongresi, 6-11 Eylül, 2017, Köstence, Romanya

Coşkun, R., Taş, A. ve Çitçi, U. S. (2016). Küreselleşme ve uluslararası işletmecilik. İstanbul: Adra Yayıncılık.

DemirgiL, H. (2008). Firmaların hayatta kalma ve büyüme performanslarinı belirleyen faktörler: Göller bölgesi üzerine bir araştırma. Yayımlanmamış Doktora Tezi, Süleyman Demirel Üniversitesi Sosyal Bilimler Enstitüsü İktisat Ana Bilim Dalı, Isparta.

Dinçer, Ö. (1996). Stratejik yönetim ve işletme politikası. İstanbul: Beta Yayıncılık

Güleş, H. K. \& Burgess, T. F. (1996). Manufacturing technology and the supply chain. Europan Journal of Purchasing and Supply Management, 2(1): 31-38.

Güleş, H. K. (1999a). Reappraising the purchasing departman's function: The influence of partnership sourcing practices. Süleyman Demirel Üniversitesi İktisadi ve İdari Bilimler Fakültesi Dergisi, 4: 47-58.

Güleş, H. K. (1999b). Elektronik veri değişiminin tedarik zinciri yönetimindeki yeri, Selçuk Üniversitesi Sosyal Bilimler Meslek Yüksek Okulu Dergisi, 3: 1-15.

Johanson, J. ve Vahlne, J. E. (1990). The mechanism of internationalization. International Marketing Review, 7(4): 11-24.

Karagöz, M. ve Demirgil, H. (2009). Firma büyüme performansını etkileyen faktörler. Süleyman Demirel Üniversitesi Iktisadi ve İdari Bilimler Fakültesi Dergisi, 14(2): 47-68.

Kayabaşı, A., Kiracı, H., Kanberoğlu, Z. ve Oğuz, A. (2010). KOBİ'lerde ihracat performansını belirleyen unsurların incelenmesi: İnegöl'de faaliyette bulunan işletmeler üzerine bir alan araştırması. Dumlupınar Üniversitesi Sosyal Bilimler Dergisi, 28: 1-9.

Kylaheiko, K., Jantunen, A., Puumalainen, K., Saarenketo, S. ve Tuppura, A. (2011). Innovation and internationalization as growth strategies: The role of technological capabilities and appropriability. International Business Review, 20(5): 508-520.

Mutlu, E. C. (2008). Uluslararası işletmecilik, teori ve uygulama. İstanbul: Beta Yayinları.

Olalla, M. F., Sanchez, J. I. L. ve Rata, B. M. (2010). Cooperation with suppliers as a source of innovation. African Journal of Business Management, 4(16): 3491-3499.

Osuna, M. A. (2014). Innovation and internationalization as a single strategy of the firm: a unification of the theories. International Journal of Management and Marketing Research, 7(1): 73-84.

Özdemir, A. (2010). Ürün grupları temelinde tedarikçi seçim probleminin ele alınması ve analitik hiyerarşi süreci ile çözümlenmesi. Afyon Kocatepe Üniversitesi İktisadi ve İdari Bilimler Fakültesi Dergisi, 12(1): 55-84.

Özparlak, A. B. (2004). Tedarikçi değerlendirmesi ve bir imalatçı firmada uygulamast. Yüksek Lisans Tezi, İstanbul Teknik Üniversitesi Fen Bilimleri Enstitüsü İşletme Mühendisliği Bölümü, İstanbul.

Penrose, E. (2009). The tehory of the growth of the firm. $4^{\text {th }}$ ed., Oxford University Press.

Porter, M. (1979). How competetive forces shape strategy. HBR, March, 137-145.

Porter, M. (1990). The competetive advantages of nations. HBR, March-April, 73-91.

Porter, M. (2010). Rekabet Üzerine. (A. Tanrıyar, Çev.) İstanbul: Optimist Yayınları. 
Rothaermel, F. T. (2015). Strategic Management. $2^{\text {nd }}$ ed., McGraw-Hill Education.

RuzzIer, M., Hojnik, J. ve Lipnik, A. (2013). Relationship between innovation and internationalization of slovenian internationalized companies, 14. Management International Conference, 21-23 November, Koper, Slovenia.

ShapiroI, R. (1986). Towards effective supplier management: international comparisons. Harvard Business School Working Paper, 9-785-062.

Ülgen, H. ve Mirze, K. (2004). İşletmelerde stratejik yönetim. İstanbul: Literatür Yayıncilik.

Weele, A. J. (2014). Satın alma ve tedarik zinciri yönetimi. (T. Binder, Çev.) İstanbul: Literatür Yayıncılık. 